metabolic product of $\alpha$-chlorohydrin which directly affects GA3Pdh, TPI and aldolase. Addition of DL-1-chloro1-deoxyglycerol-3-phosphate $(0.1 \mathrm{mM})$ severely inhibited the activity of GA3Pdh $(53 \%)$ in the reaction cuvette containing spermatozoal sonicate. One hundred times that concentration of inhibitor was required for significant inhibition of TPI and aldolase. We suggest that $\alpha$-chlorohydrin is phosphorylated on entry into the spermatozoa. The phosphorylated compound may then act as a competitive inhibitor of GA3Pdh because of its structural similarity to the normal substrate of the enzyme, glyceraldehyde-3phosphate. Further investigations of this hypothesis are presently under way.

We thank Professor C. W. Emmens for his interest and advice and the Upjohn Company of Kalamazoo, Michigan, for the gift of $\alpha$-chlorohydrin. The investigation has received financial support from the World Health Organization.

\author{
H. MOHRI* \\ D. A. I. SUTER \\ P. D. C. BROWN-WOODMAN \\ I. G. White \\ D. D. RIDLEY
}

Department of Veterinary Physiology,

Department of Organic Chemistry,

The University of Sydney,

N.S.W. 2006, Australia,

Received January 21; accepted March 24, 1975.

* Permanent address: Department of Biology, University of Tokyo, Komaba, Meguro-ku, Tokyo, Japan.

1 Coppola, J. A., Life Sci., 8, 43-48 (1969).

2 Ericsson, R. J., and Baker, V. F., J. Reprod. Fert., 21, 267-273 (1970).

Brown-Woodman, P. D. C., Salamon, S., and White, I. G., Acta. Europ. Fert. (in the press)

4 Johnson, L. A., and Pursel, V. G., J. Anim. Sci., 34, 241-245 (1972).

5 Setty, B. S., Kar, A. B., Roy, S. K., and Chowdbury, S. R., Contraception, 1, 279-289(1970)

6 Jackson, H., Campbell, I. S. C., and Jones, A. R., Nature, 226, 86-87 (1970).

7 Jones, A. R., Davies, P., Edwards, K., and Jackson, H., Nature, 224, 83 (1969),

Samojlik, E., and Chang, M. C., Biol. Reprod., 2, 299-304 (1970).

9 Crabo, B., and Applelgren, L. E., J. Reprod. Fert., 30, 161-163 (1972).

10 Brown, P. D. C., and White, I. G., J. Reprod. Fert., 32, 337-338 (1973).

11 Brown-Woodman, P. D. C., and White, I. G., Contraception (in the press).

12 Mohri, H., Mohri, T., and Ernster, L., Expl Cell Res., 38, 217-246 (1965)

13 Peterson, R. N., and Freund, M., Biol. Reprod., 5, 221-227 (1971).

15 Beisenherz, G., in Methods in Enzymology, 1, (edit. by Colowick, S. P., and Kaplan, N. O.), 387-388 (1955).

\section{Localisation of plutonium in mouse testes}

ThE plutonium isotope ${ }^{239} \mathrm{Pu}$ is a known carcinogen but its ability to produce genetic damage has not been so well investigated. The radionuclide is found in gonads after intravenous injection into humans ${ }^{1}$ and after administration to animals by various routes ${ }^{2}$. Retention of ${ }^{239} \mathrm{Pu}$ in the gonads is prolonged and the genetic effects there have been estimated on the basis of average dose in the gonads ${ }^{3}$. Inhomogeneity of distribution of plutonium within gonads has, however, been noted ${ }^{4}$ giving rise to the possibility that some cells may receive a greater radiation dose than others. No investigations of the effects of this inhomogeneity upon dose-rate to the cells involved in gametogenesis have been reported. Here we report briefly that a non-uniform distribution of ${ }^{239} \mathrm{Pu}$ in the testis results in increased radiation of the spermatogonial stem-cells.

Groups of 12-week-old male CBA mice were killed 4 or 12 weeks after intravenous injection of ${ }^{239} \mathrm{Pu}$ citrate. The plutonium in each right testis was measured radiochemically (Table 1). Autoradiographs prepared from 6- $\mu \mathrm{m}$ sections of frozen left testes showed that some $90 \%$ of the plutonium seemed to be deposited within the intertubular spaces and in the peritubular tissue immediately surrounding them.

A total of $12,000 \alpha$ tracks were counted in more than
Table 1 Radiochemical analysis of the right testis of CBA mice following intravenous injection of ${ }^{238} \mathrm{Pu}$ in $1 \%$ trisodium citrate solution

\begin{tabular}{lcc}
\hline Weeks after injection & 4 & 12 \\
Number of testes & 5 & 6 \\
Testis mass (mg, mean \pm s.e.) & $73 \pm 1$ & $67 \pm 4$ \\
Plutonium (pCi, mean \pm s.e.) & $20 \pm 3$ & $23 \pm 2$ \\
$\begin{array}{l}\text { Plutonium (pCi g } \\
\text { Average dose rate (rad d d } \pm \text {, s.e.) }\end{array}$ & $280 \pm 45$ & $350 \pm 38$ \\
\begin{tabular}{l}
$\quad \pm$ s.e.) \\
\hline
\end{tabular} & $0.072 \pm 0.012$ & $0.092 \pm 0.010$ \\
\hline
\end{tabular}

A mean activity of $88 \mathrm{nCi}{ }^{239} \mathrm{Pu}$ was injected into each mouse; $3.2 \mu \mathrm{Ci}$ per $\mathrm{kg}$ body mass.

700 randomly selected fields from 58 sections.

The $\alpha$ tracks could be categorised into: those which lay entirely above the intertubular spaces $(47 \%)$; those which lay above the peritubular membrane or above the adjoining $10-\mu \mathrm{m}$ layer of cells containing the spermatogonial stem cells $(42 \%)$; and those which lay entirely within the peritubular membranes but excluding those in group $2(11 \%)$.

On the assumption that the testis consists of a closepacked series of cylinders of uniform diameter (experimentally determined mean value $=206 \mu \mathrm{m}$ ) it was calculated that the $10-\mu \mathrm{m}$ shell of tissue surrounding each tubule and containing the spermatogonial stem-cells, constituted $17 \%$ of the whole testis mass. It was then assumed that the spermatogonial stem-cells were randomly distributed in these $10-\mu \mathrm{m}$ peritubular shells and a dose inhomogeneity factor $N$ (ref. 5) was calculated :

$$
\begin{aligned}
N & =\frac{\text { average dose to spermatogonial stem-cells }}{\text { average dose to whole testis }} \\
& =\frac{\text { fraction of all } \alpha \text { tracks in group } 2}{\text { fraction of testis mass in } 10-\mu \mathrm{m} \text { peritubular shells }} \\
& =\frac{0.42}{0.17}=2.5
\end{aligned}
$$

Therefore, from the data given in Table 1 , dose rates to spermatogonial stem-cells in our experiment were 0.18 and $0.23 \mathrm{rad} \mathrm{d}^{-1}$ at 4 and 12 weeks respectively. A value $N=2$ was also calculated directly from the model system assuming random distribution of ${ }^{239} \mathrm{Pu}$ in the intertubular spaces and taking into account the transfer of energy along the path of each $\alpha$ particle (M. C. Thorne, personal communication).

Our results show that for mice the radiation dose rate to the spermatogonial stem-cells is greater by a factor of $2-2.5$ than the average for the testis as a whole calculated directly from the total amount of ${ }^{239} \mathrm{Pu}$ deposited in the gland. This implies that the genetic effects may be proportionately greater. The validity of the factor $N$ as calculated and the biological effectiveness of $\alpha$ particles relative to other radiations are matters now undergoing cytological investigation (A. G. Searle, personal communication). It would also be important to establish comparable values for ovaries. Much more work is required to decide on appropriate values for men.
D. GREEN
G. R. HOWELlS
E. R. HUMPHREYS
J. VENNART

$M R C$ Radiobiology Unit,

Harwell,

Didcot, Oxfordshire OXII ORD, UK

\footnotetext{
Received March 3; accepted April 2, 1975.

1 Langham, W. H., Bassett, S. H., Harris, P. S., and Carter, R. E., Los Alamos Scientific Laboratory Report LA-1151 (1950).

2 Richmond, C. R., and Thomas, R. L., Health Phys. (in the press).

3 Medical Research Council, The Toxicity of Plutonium (HMSO, London, 1975). Ullberg, S., Nelson, A., Kristofferson, H., and Engström, A., Acta Radiologica, 58, 459-471 (1962). International Commission on Radiation Units and Measurements, Supplement
to ICRU Report No. 19 (1973).
} 